\title{
APPLICATION OF SELECTED METHODS OF INDUSTRIAL ENGINEERING IN ENTERPRISES IN THE CONTEXT OF SUSTAINABLE PRODUCTION
}

\begin{abstract}
Application of methods and tools of industrial engineering is from our experience often disconnected from the strategy and core activity of the company and this influences the possibility to get synergic effect for entrepreneurship and for all stakeholders including environment and future. For capturing the synergies, it is imperative to implement system approach on the all levels of management and to create innovative environment. Objective of papers is twofold. Firstly, it gives a comprehensive overview of the most used methods and tools in industrial engineering to improve quality and effectiveness in context the sustainable development. Secondly, it gives a deep insight in application of before introduced methods in companies in Slovakia featuring discussions on cross-disciplinary cutting policy issues from the management perspective, such as economical, environmental and societal impact on the stakeholders and environment.
\end{abstract}

Key words: industrial engineering, lean, case study, logistics, sustainability.

\section{Introduction}

Aim of the chapter is to give insight into main methods connected with industrial engineering used to achieve quality improvement and effectiveness as a strategic advantage on market; furthermore, are considered trends and future development in mentioned area with focus on win -win strategy for all stakeholders including environment and future. First part of paper characterizes methods of industrial engineering dealing with waste elimination (time, transportation, waiting, motion, inventory) and second part introduces specific application of industrial engineering methods (standardization using Spaghetti diagram, 5Smethod and Kanban system) using case studies and expected advantages in enterprises. Third part of article discusses method of industrial engineering from management perspective taking into account the three pillars perspective and involvement of employees as precondition of improvement and innovation in future.

\footnotetext{
${ }^{1}$ Ing. PhD., Slovak University of Technology in Bratislava, Faculty of Materials Science and Technology in Trnava, Helena.fidlerova@stuba.sk,

${ }^{2}$ Assoc. prof. Ing. PhD., Slovak University of Technology in Bratislava, Faculty of Materials Science and Technology in Trnava, Miroslava.mlkva@stuba.sk.
} 


\subsection{Characteristics and issues of selected industrial engineering methods}

Industrial engineering focuses on increasing the process productivity and the business performance. It strives to make business processes easier, faster and cheaper. Industrial engineers design, implement, plan and manage comprehensive integrated manufacturing and service delivery systems to ensure their high performance, reliability, deadlines and cost management. These systems integrate people, information, technological equipment and processes, materials and energy throughout the lifecycle of the product or service. As seen from above mentioned there are many synergies between industrial engineering and quality management.

Nowadays any company, which wants succeed, ought to minimize activities, which don't add value [1]. These are considered as waste e.g. unnecessary financing costs, storage costs, worthless stock of old items etc. Muda of Overproduction and Muda of Inventory are the most common ones (TPS).

Muri (Overburden): Eliminating overburden of equipment and people is one of the main principles of the Just-In-Time system, the main pillar of the Toyota Production System. To avoid overburden, production is evenly distributed in the assembly processes.

Mura (Unevenness or irregularity): Eliminating unevenness or irregularities in the production process is one of the main principles of the Just-In-Time system, the main pillar of the Toyota Production System.

The third of three types of waste mentioned within the Toyota Production System, notably identified and leveled through the application of Heijunka principles and Kanban devices. Workflow is also smoothed by requiring members to operate multiple machines — also known as 'multi-process handling' — within any particular process, and by predicting and preparing for times of high demand [2].

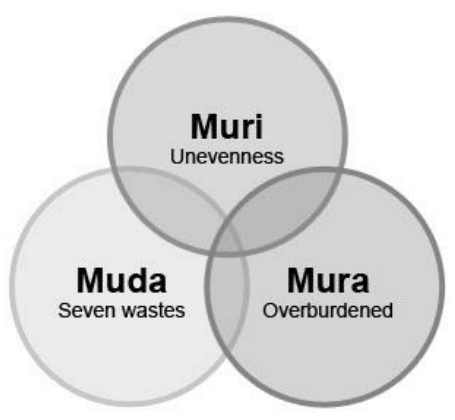

Fig. 1. Japanese words forming $3 M U$

Source: [3] 
By the lean manufacturing philosophy, any waste ought to be eliminated; it is called in Japanese - muda. The term muda refers to those activities that do not add value. Muda at a workplace can be divided in seven categories [4]:

$>$ Muda of over-production, when a greater production of products is produced then it is required by customers. Overproduction leads to wasting of materials, energies and human work;

$>$ Muda caused by unnecessary stock- this type of wasting is caused due to overproduction and purchasing for storage or storage of spare parts, not finished goods and finished goods. These items require additional costs;

$>$ Muda caused by defects - every defect means extra costs for reworking the part, rescheduling production, etc.;

> Muda caused by unnecessary movement of employees connected with the efficiency of their work causing a waste of physical power e.g. when removing staff to get spare parts;

$>$ Muda caused by inappropriate processing, use of the wrong technology can cause the deficit because of long production launching times and long working operation times;

> Muda caused by waiting - caused by the lack of components, consumables and equipment or by a damaged machine or unstable production.

$>$ Muda caused by transport - transport is an inseparable part of the production processes which cannot be removed, however it does not give any value to the final product and this is why it should be minimized.

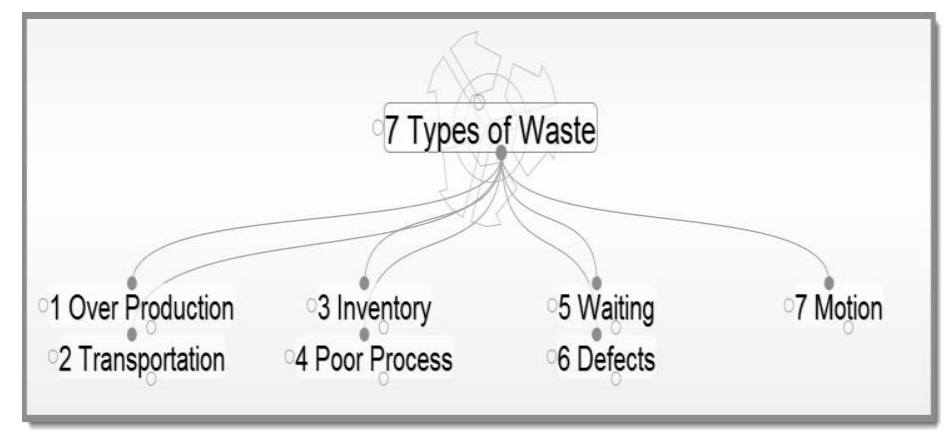

Fig. 2. Seven types of waste

Source: [3]

The core idea of methods of lean production is to maximize customer value while minimizing waste. Simply, lean means creating more value for customers with fewer resources.

Lean management is a philosophy of management, involving the continuous elimination of waste, defined as all activities, investments and processes which do not 
add value to the product or service from the customer point of view [5] To eliminate sources of wasting, within the concept of lean production, various tools and methods are used that serve not only for searching problems but also to remove them. On the other hand, individual tools are often interdependent; the successful implementation of one tool can be conditioned by the implementation of another tool.

A lean organization understands customer value and focuses its core processes to continuously improve them. The ultimate goal is to provide perfect value to the customer through a perfect value creation process that has zero waste.

Sustainable lean management is achieved not through a reduction in employment or increasing workload, but thanks to the commitment of all employees in the process of improving the system [5].

Main ideas of lean management are as follows according Dirk Bosenberg, Heinz Metzen, [6] :

1. Proactive thinking or optimism of creation: these are future deeds that are deliberately thought through and formulated. Optimism and just proactive thinking are already present with Western managers. They certainly do not just want to go like a crowd, but with their attitude they evoke the virtues of a robot, a willingness to adapt. While pro-active thinking is trendy, the image of the crisis manager, which grows and responds quickly, continues to persist in the wider public.

2. Sensitive thinking or preparedness for change: it is necessary to focus on the environment, to change it, to take it into account and to adapt to the environment with all the senses we have. It is very important to be open to problems and to be able to cope with the crisis without unnecessary stress. The basic step is self-knowledge, because this is just the first step to improvement. Maasaki Imai explains to the Western manager that, in addition to inadequate proactivity, they also do not appreciate mistakes and problems as something of value. Sensitivity itself includes sensory and emotional intuition. The basis of sensitive thinking is information openness.

3. Overall thinking or regional and market integration: you need to realize the effect of thinking on the whole and prove the courage to be comprehensive. An entrepreneur himself is a person who knows what he wants and wants to pursue, but does not use more resources than necessary. Slim entrepreneurs therefore know more: managing, developing, creating a business is a comprehensive, complex process focused on the environment in which it participates, but it cannot decide on the outcome itself. The basis of the overall thinking is patience and respect, it is also necessary to be aware of the economic-organizational reality, which is the dominance of the market economy over the centralized planned economy.

4. Potential thinking or making available of all resources: this is the use of all the resources at our disposal. The basis of potential thinking is to use collaborators, 
suppliers, customers and competitors, to eliminate the distinction between thinking and work, to eliminate misconduct, to disrupt the main activity due to maintenance or other activity, to create the same interests, to constantly ask why resources are not used, to avoid inadequate handling or overload.

5. Economic thinking or prevention of any waste: the basis of economic thinking is to eliminate unnecessary waste.

Two main method groups are used to eliminate waste in organization according Košturiak, Frolík [7]:

1. Basic methods are methods aimed at mostly narrow set of issues of the production system. The result of their use is a key process improvement. These methods are mostly simple, well assessable and their advantage is that they bring first useful results in a short period of time. The basic methods ought to be considered as a basis for improvement. Among them belongs Ishikawa diagram, checklist, $5 \mathrm{~S}$ etc.

2. Sophisticated methods are methods combining basic methods into a system and they presume more experience in this area and are more time and finance demanding (Six sigma).

Tools and methods of industrial engineering can be divided in groups as follows [8] :

$>$ Value Stream Mapping: identifies processes and process steps, into processes adding value to the product from the customer's perspective and the processes that do not add value and indicates the processes that need to be eliminated;

$>$ Optimization of material and information flows - process maps, optimization of production deployment - new layout, stocks reducing, introduction of Kanban method - replenishment of stores according to actual need;

$>$ SMED (Single Minute Exchange of Dies) - method ensuring the flexibility of production so that it can be able to produce, in small amounts, according to actual requirements of customers;

$>$ Methods for product quality improvement - Poka - Yoke, PDCA, Kaizen, Just-InTime, Six Sigma, etc.

In the next part of article are described some selected tools and methods that are most often applied in Slovak organizations. We approached this insight on the basis of the long- term analysis and experience from industrial organizations within students' final theses and projects and on the basis of a survey conducted in the framework of the research project. 


\section{Spaghetti diagram}

The spaghetti diagram is used to minimize excessive movement of people, information or material. It is also used in places where it is necessary to know the relation of performance per a worker or place [9].

Tracking the worker movement is not the only thing that is to follow. It is also possible to monitor a material flow in the production process or within the logistic chain, the information flow across the process or department. This measurement captures the flows in a given time period. While monitoring an employee, all his movements are captured in the layout of the workplace. The objective for using this method is to increase productivity, to define standard time and to eliminate the ineffectiveness. As it can be seen in figure 3, the record begins with drawing the layout of the production areas. Then is recorded the movement of monitored objects on the desktop not as a straight line, but rather should correspond to the real tracking paths. It is advisable for larger numbers of lines, to choose different colors for different objects due to the easier orientation. The result is a map of the monitored objects, which ought to serve for designing the ideal future state. [10]

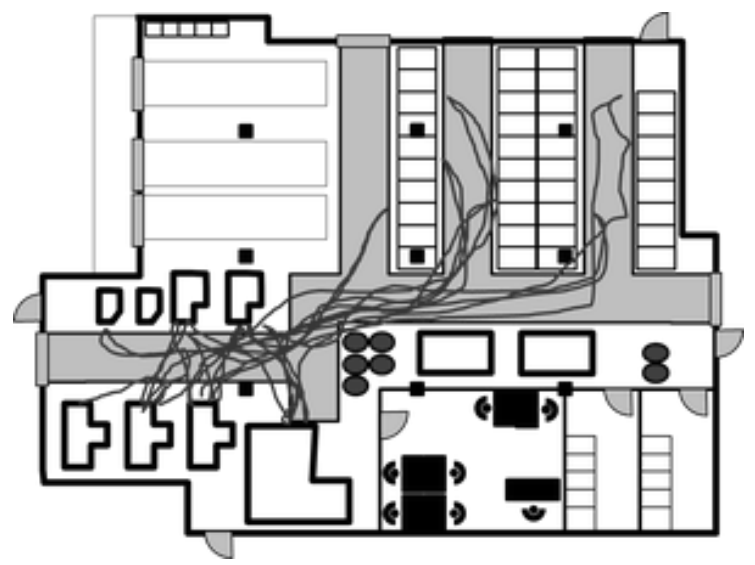

Fig. 3. Example of a Spaghetti Diagram

Source: [11]

\section{S Method}

The 5S method is based on the assumption that essential conditions for the production of high quality products and services in the organization are order, cleanliness, standardization and discipline in the workplace. It is characterized by minimum or no waste and high productivity.

5S methodology has several basic principles according Sinay et al. [12]:

$>$ the cleaner workplace is the sooner problems can be identified, 


\footnotetext{
$>$ a cleaner workplace means more safety,

$>$ a frequent and well organized environment is more predictable,

$>$ standardization and workplace organization enables faster responses,

$>$ communication about current situation in manufacturing process is easier.

The $5 \mathrm{~S}$ method comprises the application of the 5 steps in following sequence as many authors state $[12,8]$ :

1. Seiri (Sort): department of unnecessary things in the workplace and their removal;

2. Seiton (Stabilize): the arrangement of all the things that remain in the workplace after the first step in a transparent manner;

3. Seiso (Shine) maintaining a clean working environment;

4. Seiketsu (Standardize): implementation of standards and the continuous implementation of the previous steps;

5. Shitsuke (Sustain): building self-discipline.
}

\section{Kanban}

The Kanban system is one of the methods to reduce and optimize inventory without making a large investment while increasing the efficiency. The main principle is to streamline inventory management. It is commonly agreed by numerous authors that Kanban has benefits for industrial enterprises because it assist with reducing waste and costs $[13,14]$.

The Japanese term Kanban simply means card or ticket. They are typically enclosed in a protective vinyl cover and contain the following information: part number and name, process name where the Kanban is to be used, number of units in the standard container and type of packing, number of Kanban cards issued, preceding process outbound stock point number, and subsequent process inbound stock point number.

The Kanban system principle is that it is produced only if there is a demand for a particular product; it means that the system works according to customer requirements -pull system [13]. This ensures that customers get exactly what they want when they want it. Sustainable pull emulates the tendency of natural systems to move materials through their structures only as they are required by the next step in the cycle. [13]

Kanban system can be considered as an effective method for managing and monitoring a material flow. It is also understood as an information system whose role is to the production control. Also, this system was introduced as part of lean manufacturing at Toyota Motor Corporation, based on just-in-time philosophy. The core idea is flexible systems that produce the necessary units, components and elements in the required time and amount. Kanban system ought to be based on real and actual values it has no sense to be implemented in the company.

Fundamentals of Kanban [15]: Kanban card representing an order for both internal and external customers and are used to transfer information; 
Kanban table is a basic visual element for information about the location where the internal vendor receives information about internal customer requirements;

Kanban clipboard is the place for storing kanban cards, where the customer inserts his / her requirements.

Two basic types of Kanban cards:

- Commanding production-ordering (Kanban production) - informs about the number, type, and consumption of material time produced by the previous process.

- Kanban lifting (withdraw) - provides detailed information about the materials to pick up the next process.

Kanban cards can be considered as an information resource that contains information about the product and on its way through the process. The use of a bigger amount of Kanban cards can disrupts the entire system and is a waste in the form of inventory. Conversely, if there is not enough Kanban card, as actually needed, it can cause interruption of the production line.

\subsection{Case studies with application of selected industrial engineering methods in companies in Slovakia}

The next part of article addresses the application of selected methods in industrial enterprises.

First organization deals with production of assembly and folding of car dashboards, from start to finish using semi-automated manufacturing lines. The analysis was focused on the assembly of panels because it is the most important part regarding production volumes. The production involves twenty assembly lines, but the project was focused only on the specified production line (see Fig. 4) with six employees working on one or more workstations and a leader of the line in charge to streamline the production line and responsible for administration.

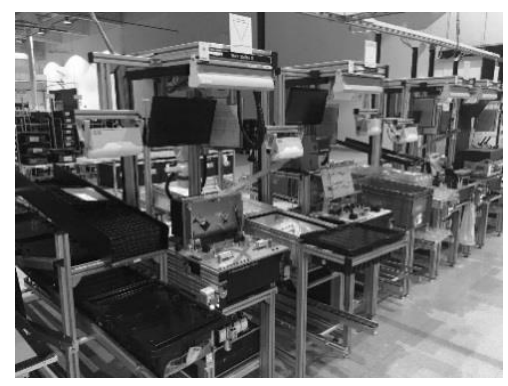

Fig. 4. The manufacturing line

Source: [16] 
The main reason for selection and monitoring above mentioned workplace was lower number of dashboards produced in the specified time period. As seen in the fig. 5 , in the company had been already recorded the movement of employees within the production line and the individual workstations with dashboard assembly operations. The supply lines for each station were described, as well as the final testing and packaging of the finished and tested product in a box, ready for export.

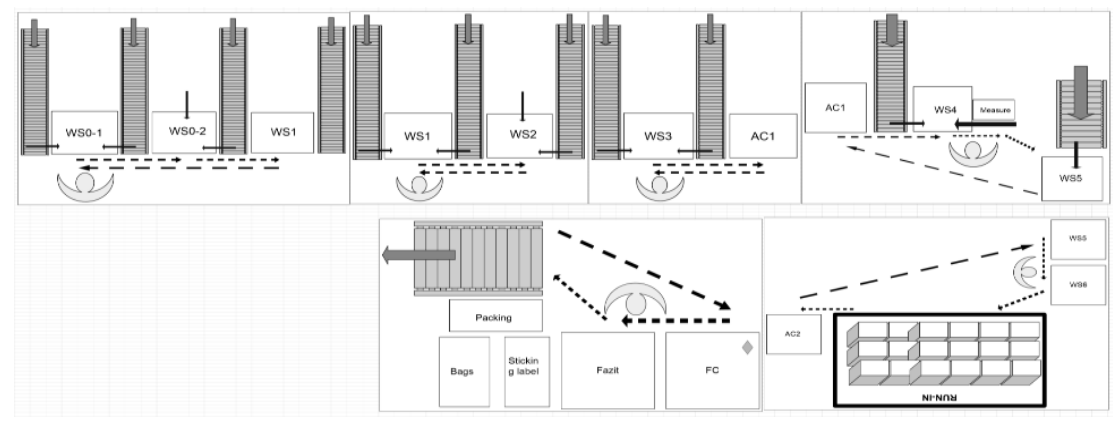

Fig. 5. Scheme of the production line

Source: [16]

The production of the dashboard consists of four production stations where the product is assembled in few steps and five control stations where the required parameters are controlled. At the last station, all the functions of the product are checked again, the surface quality is checked, and it is then placed in the plastic container and placed in the prepared box.

By means of analysis and measurement of time consumption, chronometric analysis, any deviations from defined standards in the production process and supply were recorded. The time analysis of the workplace didn't indicate any serious problems that ought to be improved. However, during the analysis a main problem on the production line was a material supply. In the process of supplying the line, there was a visible loss of time within movement of employee, and thus the productivity of the workplace was reduced. The procedure for supplying the workplace can be described as follows: The delivery time was set to 51 minutes, where the material was delivered to the production line using an automatic trolley (AGV trolley). This automatic trolley brought to the line all the material needed to streamline production.

All components had their places in the production line where they need to be loaded, as well as their specific box in which every pieces of material ought to be stored. The trolley with the material had to be manually unloaded into supermarkets on the line and thus stocked for further continuous production. This work was always 
carried out by an employee from the production line who stops work on the line for the time required for unloading and supply of the supermarkets with the material. In addition to provide the material the employee had to stock empty packaging of the material and to return the waste back to the trolley, taking it to the warehouse, where it is by other employee dispensed.

The material in shelves is specific for each workstation regarding various dashboard assembly operations. By means of measuring and observing the process, it was determined that activity of employee responsible for unloading a material trolley, indicates too many unnecessary steps and operations. Handling the material was chaotic without any specified order. As a result, it can be said that in this operation ought to be reduced the time and wasting time thus increase the effectiveness and the hourly performance of the production line. The entire process of supplying the line, walking and movements of employee were recorded using the Spaghetti diagram shown in Fig. 6.

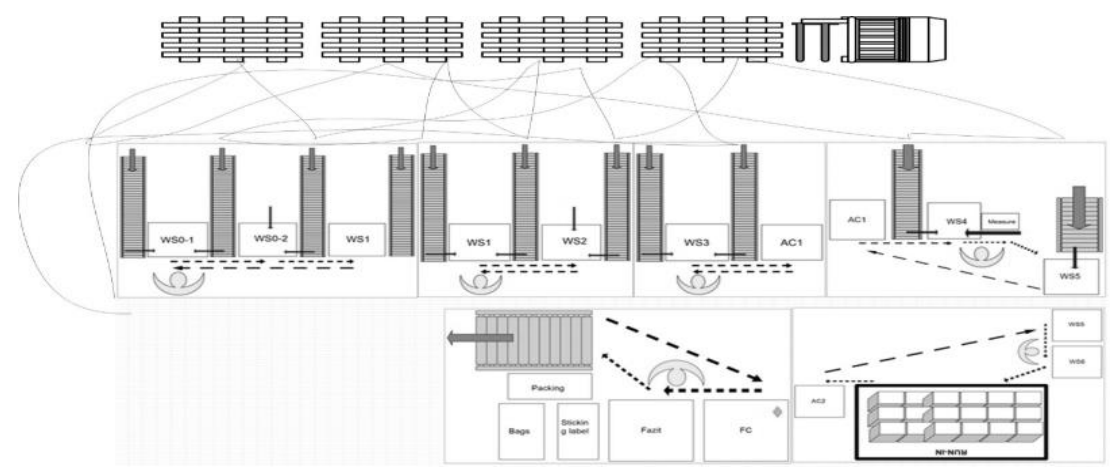

Fig. 6. The spaghetti diagram of employee movement before change

Source: [16]

As shown in the spaghetti diagram above, the employee activity includes many unnecessary steps which need to be eliminated. The process was indicated as a very inefficient and unorganized.

During analysis not only steps and movements of the employee were measured but also the total time needed for unloading the material and loading the empty packages. The total time for material unloading was eight minutes that was within of 7.5 hours shift cca 60 minutes of non -productive time. Since employee was not on the workplace, the line didn't produce according planned productivity of 51 units per hour. 
Such wastage means the production of 3 less products per hour, 24 products for a shift, and for a three-shift working it is a loss of up to 72 pieces in the monitored process some reserves and possibilities for improvement can be identified. In order to to follow step by step which material and in what order should be placed in the line, was recorded a video of the process.

From the obtained information, the procedure of material supply was simulated, taking into account all the possibilities of loading, while minimizing the movement of the employee and the time of unloading. Thereafter, the procedure was introduced to all employees on the production line. All employees were trained and under the supervision of the trainer they learned the right sequence of steps in procedure.

Employees could adapt to the new way of loading during specified training time, and then the timeframe and the spaghetti diagram as a verification of the improvement ought to show real time savings and footsteps reductions

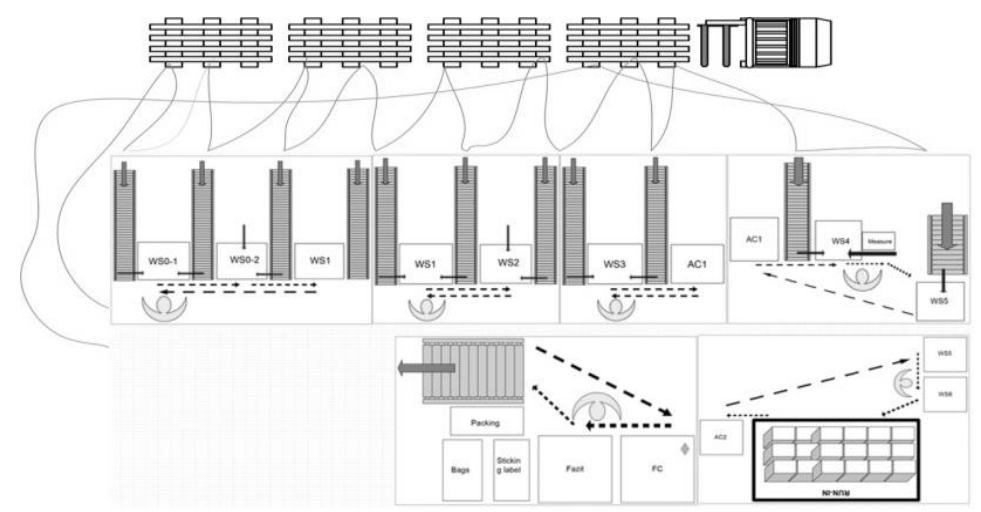

Fig. 7. The spaghetti diagram of employee movement after change

Source: [16]

The cycle time before change was set for 480 seconds ( 8 minutes), the new material delivery method had a 240 second cycle time (4 minutes). The spaghetti diagram created upon the improvement is shown above (Fig. 7). Here is to consider a reduction of worker's walking versus the previous situation. Compared to the previous situation without standardization the new solution offers a standardized material unloading procedure, with reduced material loading times and a minimizing of employee steps. The suggested optimization of the material supply process is 240 seconds less compared to the previous process, which represents significant time savings.

Another problem, identified during analysis for elimination of waste in enterprise, was the unnecessary ejection of LCDs, which after careful analysis can be repaired and used in the production process. Procedure for these displays was proposed to 
analyze the displays directly within the production line and to divide them into a supplier's error or operator error.

The analysis can be performed on the rework workplace. This workstation, before and after installation of the analyzing tool (microscope), is shown in fig. 8.

The first step of project was to develop a workflow that clearly and short defines how the display error should be conducted. For company was important to know, whether it can be identified as a supplier's mistake or an employee mistake and how to proceed with records about the display.

The second step of project was to train line managers who will be in charge of analyzing displays with defects. As parts of the training, workers were familiar with a workflow, trained how to prove and analyze the display, how to distinguish cause of defect, and how to proceed with the record about the display defect for reporting purposes. The training was focused on comprehensive information about of the work with the microscope, its parts, as well as its functions, the lighting setting etc.

As the third step of project, the microscopes were assembled and used on the individual production lines. Due to small size and manipulability of the selected microscopes, radical workplace modification was not required. The microscope required not much space and had no effect on other activities at the workplace.

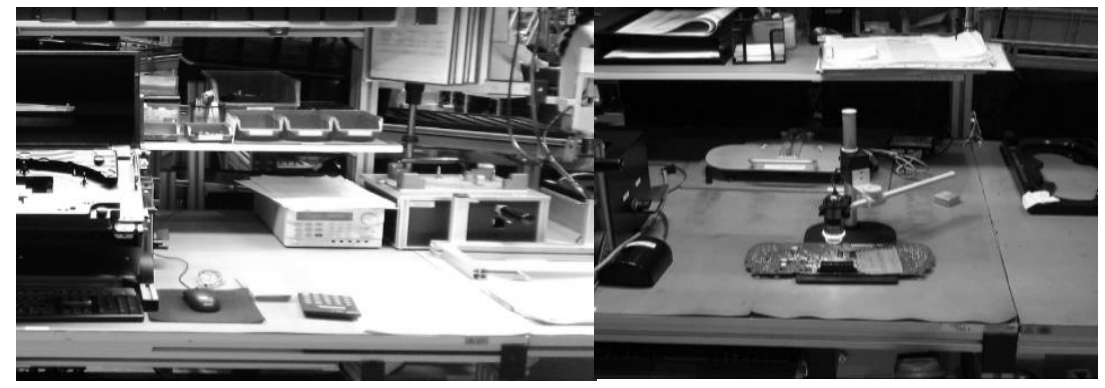

Fig. 8. Workplace before and with microscope

Source: [16]

This improvement, compared to the previous situation, when the displays were not analyzed in any way, but just dropped into the scrap, should bring advantages for the enterprise. Revealing and defining the causes of defects reduce its scrap costs.

By applying above described methods for waste elimination, in the first solution was optimized the process of supplying the production line with materials, achieving reduction of time and elimination of financial losses and minimized no productive move of employee and the second part of project was focused on cost reduction for scrap. 
The second in paper considered organization as a case study deals with the production of ropes, threads and yarns. The implementation project of industrial engineering methods was focused on eliminating waste by application of $5 \mathrm{~S}$ method in the rope production. On the basis of the analysis, following failures were detected: contaminated floors, tools and workstations placed on the floor and on machines, unmarked storage places for tools, lack of information visualization, etc. For improvement $5 \mathrm{~S}$ method and its tools were applied.

As a precondition of successful application of $5 \mathrm{~S}$ method was specified $5 \mathrm{~S}$ team. Its role is to provide a training of employees, implementation of the method, administration, etc.

Before the $5 \mathrm{~S}$ method implementation is required a training to ensure that all employees in the workplace are informed about the method, the sequence of steps in the method, the benefits and possible $5 \mathrm{~S}$ problems.

The first step of the S method is "Sorting". In this step, all the objects in the workplace are marked with the color labels. Based on frequency of their use, objects were marked red (items without use found in the workplace); yellow (items with unclear purpose) and green labels (required items). Items marked with yellow labels have to be moved to the temporary storage zone (Fig. 9) and after 30 days, the use and importance of the item ought to be reassessed and its placement reviewed.

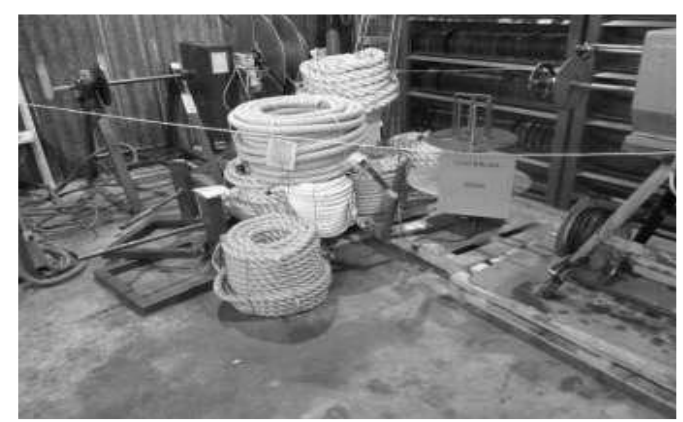

Fig. 9. Temporary storage of items with unclear purpose in central zone Source: [17]

The next step of the "Stabilize" was to find a place to store the items for work and mark them so that anyone could find them and give them back to their place after use. The checklist form for the item list was created, placed on the information board (see Fig. 10). 


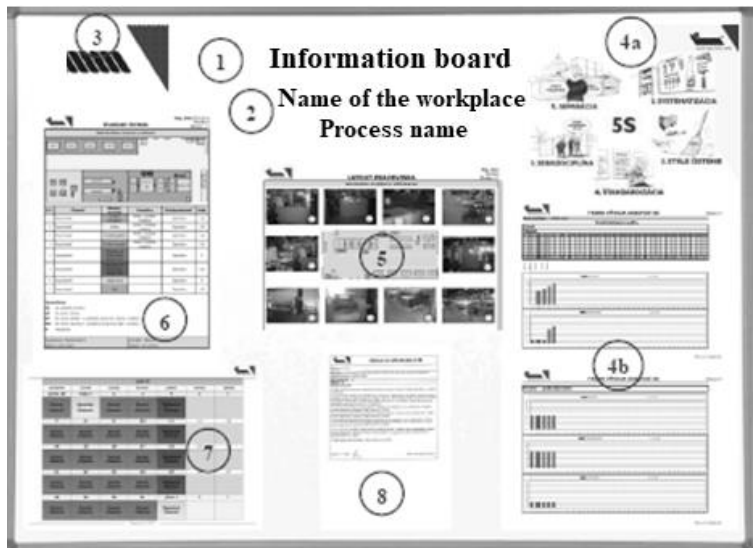

Fig. 10. Information board

Source: [17]

In the third step "Shine", individual cleaning zones were defined and the cleaning standards were specified for each workplace. During analysis many cleansing aids were found on various places, so it was necessary to locate and visually mark the location of these devices (Fig. 11).
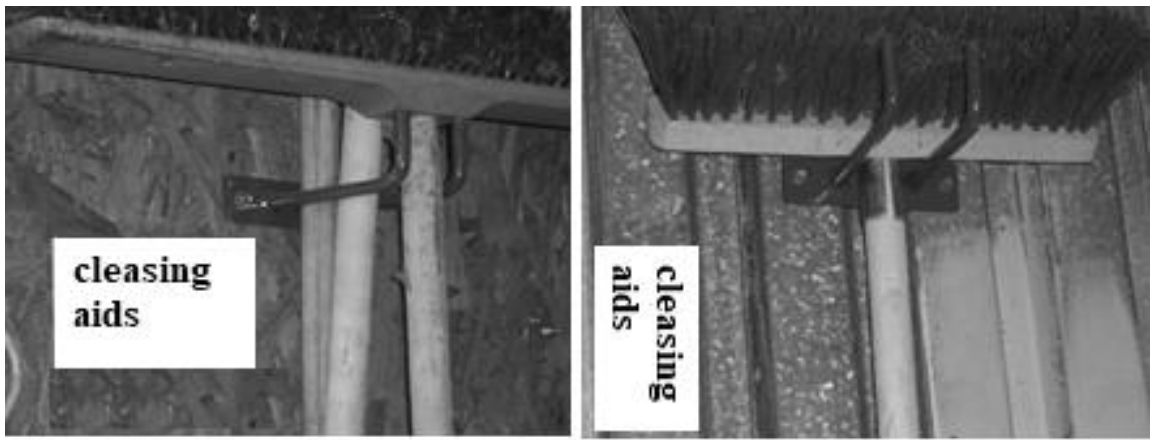

Fig. 11. Marking the places for cleaning devices

Source: [17]

Subsequently, a monthly cleaning schedule was established, in which daily, weekly and monthly terms were set for individual zones, eventually devices. The cleaning schedule was published also on the information board (Fig. 10)

The fourth step of the 5S "Standardization" method is mainly to standardize all maintenance-related activities in the workplace and to maintain the status obtained after the implementation of the first three steps of the $5 \mathrm{~S}$ method. Here, you need to 
create a visual standard of workplace that captures all activity and placement of individual items in the workplace. The purpose of the standard is that the prescribed activities ought to be done in the same way, in the same time and with the same result.

The fifth, last step of Method 5S, "Sustain" is to create a long-term habit. As part of this step, necessary audits ought to be carried out at regular intervals to verify compliance, cleanliness at the workplace, and compliance with established standards. As main benefits achieved applying described method were elimination of items without use at the workplace, arrange the necessary items in order to eliminate time when looking for a tool. On the other hand, it is important to mention that the $5 \mathrm{~S}$ method application needs to be seen as a process that needs to be constantly improved.

Aim of the project in third introduced organization was using Kanban to optimize the company's inventory management, to suggest measures to minimize inventory and thus costs and to maximize production in an effective and sustainable way. The effectiveness and sustainability was focused on streamlining the inventory management through actualization and improvement of existing system Kanban. It was proposed application of the Kanban method because its principles are to eliminate waste.

The production program of the company was focused on the production of solenoids for hydraulic and electromagnetic coils for the automotive industryOne of the possibilities for improve effectiveness is to reduce the capital tied up in stocks of the company.

The company has implemented the Kanban system a few years ago, so it was decided to improve existing Kanban system in chosen production line. The proposal to update the manual Kanban system was implemented in a specific production line chosen because some its products has almost no customers, and vice versa, some of them with prognoses of increase in consumption.

This project should serve as a trigger factor for updating the system Kanban also on other production lines operating on this principle.

The production line used a Kanban system for 4 kinds of products characterized as outputs A, B, C, D under identification numbers in SAP (Table 1). Table 1 shows the maximum amount of semi products for transport unit and the amount of Kanban cards for the product.

Materials A, B, C, D should have a constant and regular consumption, a high degree of production repeatability, a higher proportion of the revenues and flexibility of the workers. As a condition for use of this system in right way it is also necessary to properly design the layout of workplaces - line arrangement. So the requirements for Kanban system application had been met on this production line. 
Table 1. Maximum amount of semi products for transport unit and the number of Kanban cards for the product.

\begin{tabular}{|c|c|c|c|}
\hline Label & Identification number & $\begin{array}{l}\text { Container capacity } \\
\text { (Maximum amount of semi } \\
\text { products for transport) }\end{array}$ & $\begin{array}{l}\text { The amount of Kanban } \\
\text { cards for the particular } \\
\text { product. (pc) }\end{array}$ \\
\hline A & 4303176 & 800 & 5 \\
B & 4343345 & 480 & 1 \\
C & 4343346 & 800 & 4 \\
D & 343347 & 480 & 4 \\
\hline
\end{tabular}

Source: [18]

For an effective and sustainable Kanban system it is very important during its implementation to calculate and determine the required number of Kanban cards to meet the current customer's requirements. The exact determination of the Kanban cards amount is the cornerstone of inventory reduction. For calculation of the required number of Kanban cards was proposed the Toyota model based on average consumption, which is almost independent from the human factor [19].

$$
y=\frac{D T(1+x)}{C}
$$

$\mathrm{Y}$ - number of cards

D - demand per unit of time

$\mathrm{T}$ - lead time

C -container capacity

$\mathrm{X}$-buffer, or safety factor

Demand per unit of time - this information can be obtained from Table 2, with the actual consumption of finished products lines based on consumption values provided per month in the time period 2 months. The average consumption per day can be calculated based on these values.

Lead time includes waiting time when the card is received from the input space to the output and the processing time during which a given dose of the parts is produced and the time of transport to the customer. Time under ideal conditions where the production line is manufacturing only one type of product should be one day. For this reason, we count the lead time as three days.

Safety factor - this factor takes into account possible variations in the case of risks in production. The coefficient is in this case determined as real value -2 . If we would like to determine a too pessimistic and an optimistic estimate, we would have to adjust this 
coefficient. The pessimistic estimate, takes into account potential risks such as lack of materials, downtime, failure, etc. The safety factor should have a value of 3.5. On the other hand, an optimistic estimate does not take into account the possible risks and is estimated for an ideal condition- continuous production, enough material sources. The value of such an ideal coefficient is 1.5. A pessimistic and an optimistic value of the safety factor can be seen as a maximum and minimum limit of Kanban cards.

Container capacity is the maximum number of material pieces for the transport unit determined by the company (see table 1). Henry et al. [20]. has suggested some practical values for the variables $\mathrm{C}$ and $\alpha$. The value of $\mathrm{C}$ is limited to a maximum of $10 \%$ of demand and $\alpha$ is a policy variable, which is decided by the management up to $10 \%$ of the demand.

Table 2. Monthly and daily consumption of semi-finished output of chosen line

\begin{tabular}{|c|c|c|}
\hline $\begin{array}{c}\text { Semi-finished } \\
\text { output of line }\end{array}$ & $\begin{array}{c}\text { Average consumption of } \\
\text { Semi-finished products } \\
\text { - monthly (pieces) }\end{array}$ & $\begin{array}{c}\text { Average consumption of } \\
\text { Semi-finished products - } \\
\text { daily (pieces) }\end{array}$ \\
\hline A & 12540 & 627 \\
\hline B & 40 & 2 \\
\hline C & 4340 & 217 \\
\hline D & 1480 & 74 \\
\hline
\end{tabular}

Source: [18]

Table 3. The actual quantity for the Kanban card of semi-finished product A

\begin{tabular}{|l|c|c|c|l|c|}
\hline $\begin{array}{l}\text { Semi-finished } \\
\text { product A }\end{array}$ & $\begin{array}{l}\text { D- demand } \\
\text { per unit of } \\
\text { time }\end{array}$ & $\begin{array}{l}\text { Lead } \\
\text { time }\end{array}$ & $\begin{array}{l}\text { Safety } \\
\text { factor }(\mathbf{1} \\
\mathbf{+})\end{array}$ & $\begin{array}{l}\text { C } \\
\text { container } \\
\text { capacity } \\
\text { (pc) }\end{array}$ & $\begin{array}{l}\text { Y- number } \\
\text { of cards } \\
\text { (pc) }\end{array}$ \\
\hline Optimistic & 627 & 3 & 1,5 & 800 & $\mathbf{4}$ \\
\hline Pessimistic & 627 & 3 & 3,5 & 800 & $\mathbf{9}$ \\
\hline $\begin{array}{l}\text { Realistic (the } \\
\text { most likely } \\
\text { estimate) }\end{array}$ & 627 & 3 & 2,5 & 800 & $\mathbf{6}$ \\
\hline
\end{tabular}

Source: [18]

According the above considered Toyota model the actual quantity for the Kanban card was determined. (table 3 , table 4 and table 5) where the calculation defined as pessimistic, optimistic and the most likely estimate. The results in the following tables are rounding to whole numbers always up. 
The calculation showed that, in the case of ideal conditions it would be sufficient to use four Kanban cards. However, in practice the ideal conditions usually do not occur, so it is necessary to take into account the possible shortcomings and problems. In this case, the number of Kanban card should be nine. This higher number was due to the higher safety factor. The most realistic number of Kanban cards, which points out that the current required number of Kanban cards, is six. In this case, it was proposed to increase the number of Kanban cards from five to six Kanban Cards.

Semi-product B can be indicated as unique, because its consumption is 0 in specified time period, so its consumption per day is determined as only two pieces. The semi product B didn't meet the requirement for the Kanban application because had no regular consumption. According to customer delivery plans are no plans to raise its consumption in next months, so for semiproduct B is no need of Kanban card.

Table 4. The actual quantity for the Kanban card of semi-finished product $C$ according the Toyota model

\begin{tabular}{|l|l|c|l|l|l|}
\hline $\begin{array}{l}\text { Semi-finished } \\
\text { product C }\end{array}$ & $\begin{array}{l}\text { D- demand } \\
\text { per unit of } \\
\text { time }\end{array}$ & $\begin{array}{l}\text { Lead } \\
\text { time }\end{array}$ & $\begin{array}{l}\text { Safety } \\
\text { factor }(\mathbf{1} \\
\mathbf{+ x )}\end{array}$ & $\begin{array}{l}\text { C container } \\
\text { capacity } \\
\text { (pc) }\end{array}$ & $\begin{array}{l}\text { Y-number } \\
\text { of cards } \\
\text { (pc) }\end{array}$ \\
\hline Optimistic & 217 & 3 & 1,5 & 800 & $\mathbf{2}$ \\
\hline Pessimistic & 217 & 3 & 3,5 & 800 & $\mathbf{3}$ \\
\hline $\begin{array}{l}\text { Realistic (the } \\
\text { most likely } \\
\text { estimate) }\end{array}$ & 217 & 3 & 2,5 & 800 & $\mathbf{3}$ \\
\hline
\end{tabular}

Source: [18]

Calculation of the required quantity of Kanban card for the semi product $\mathrm{C}$ was shown above in Table 4. It is clear that the most realistic number was three Kanban card. Therefore, we proposed that the original four Kanban cards ought to be reduced to three Kanban cards.

According to the latest calculations (table 5), the stock D can determine the amount of Kanban cards from four to two Kanban cards because the consumption of this stock has been reduced for the last year. It is to mention that consumption is a very important factor in determining the required number of Kanban cards, so it is very important to monitor the actual consumption and make modifications to the Kanban system according it. 
Table 5. The actual quantity for the Kanban card of semi-finished product $D$

\begin{tabular}{|l|l|l|l|l|l|}
\hline $\begin{array}{l}\text { Semi-finished } \\
\text { product D }\end{array}$ & $\begin{array}{l}\text { D- } \\
\text { demand } \\
\text { per unit } \\
\text { of time }\end{array}$ & $\begin{array}{l}\text { Lead } \\
\text { time }\end{array}$ & $\begin{array}{l}\text { Safety } \\
\text { factor(1 } \\
\mathbf{+ x} \text { ) }\end{array}$ & $\begin{array}{l}\text { C } \\
\text { container } \\
\text { capacity } \\
\text { (pc) }\end{array}$ & $\begin{array}{l}\text { Y- } \\
\text { number } \\
\text { of } \\
\text { cards } \\
\text { (pc) }\end{array}$ \\
\hline Optimistic & 74 & 3 & 1,5 & 480 & $\mathbf{1}$ \\
\hline Pessimistic & 74 & 3 & 3,5 & 480 & $\mathbf{2}$ \\
\hline $\begin{array}{l}\text { Realistic (the most } \\
\text { likely estimate) }\end{array}$ & 74 & 3 & 2,5 & 480 & $\mathbf{2}$ \\
\hline
\end{tabular}

Source: [18]

The results of calculating the actual amount of the required Kanban cards indicates that the original number of Kanban cards should be changed. For this reason, it was proposing to change the number of Kanban cards according to the calculation - the realistic, pessimistic or optimistic estimates.

The introduction and update of Kanban method requires the high quality and the standardization of the process. Any deviation and error in the system should always be evaluated on the basis of the observed and calculated values should be adopted and corrective measures.

It was proposed that all employees working with the system Kanban should attend at training to know the main principles of Kanban. It is important that the staff is aware that any mistake or loss of Kanban cards can endanger the continuity of material flow and supply of materials to the customer. The number of Kanban cards can be controlled using the identification numbers of each Kanban card. Furthermore, one of suggestion for improvement was providing clear and actual information in the form of directives and procedures and also to determine the person responsible for periodical updating of Kanban (calculation of required Kanban cards, regular updates, replacement of damaged Kanban cards, etc.).

One of the key issues encountered within the implementation and use of the industrial engineering methods in companies in Slovakia is the misunderstanding of the differences. Methods are implemented inconceivable; often the solution priority is focused on no-core processes with a minimal impact in the context of the company's total value stream and without connection to the strategy. The implementation of these methods is lacking in the system - it ought to be a sophisticated sequence of implementation steps, the next step cannot begin without the previous step being over following strategic goals of company. 


\section{Summary}

Every organization wants not only to survive but also improve its competitiveness in today's turbulent environment, and therefore needs to enhance its processes and to minimize waste, which can be helped by the application of industrial engineering tools and methods to reduce waste. Waste can be understood as everything that does not add value to society and means more cots, so every company must get rid of all activities that negatively affect its effective functioning. As very important we consider involvement and training of all employees to achieve sustainable production processes without waste in the company.

\section{Bibliography}

[1] KADÁROVÁ, J. 2012. Wastage in industrial enterprise. [online]. [2015-08-31]. http://www.sjf.tuke.sk/kpiam/TaIPvPP/2012/index.files/clanky/46\%20Jaroslava\%20KAd ArovA\%20Plytvanie.pdf .

[2] Muda, Muri, Mura - Toyota Production System guide. Online http://blog.toyota.co.uk/muda-muri-mura-toyota-production-system [cit. 2018-04-28].

[3] KuČerová, M., MĹkva, M., Sablik, J., Gejguš, M. 2015. Eliminating waste in the production process using tools and methods of industrial engineering. In Production Engineering Archives. Vol. 9, No. 4 (2015), pp. 30-34. ISSN 2353-5156.

[4] BEŇO, R. 2011. Plytvanie (Muda) na pracovisku z hladiska ergonómie. Muda on the workplace from ergonomy viewpoint. In: Nové trendy v manažérstve kvality. New trend in quality management, 12-13 april 2011, Trnava: AlumniPress, 2011. pp. 33-38, ISBN 978-80-8096-143-5.

[5] INGALDI M., JAGUSIAK-KocIK M.2014. Lean tool used in the automotive industry. in Journal PRODUCTION ENGINEERING ARCHIVES No. 3, Vol. 4, 2014, pp. 7-10, ISSN 2353-5156.

[6] Bosenber D., Metzen H. 1999: Lean manažment. BRATISLAVA: SLOVO. pp. 18-52. ISBN 80-85711-16-8.

[7] KošturiaK, J., FrolíK, J. 2006. Štíhlý a inovativní podnik. Praha: Alfa Publishing, s.r.o., 2006. 237p. ISBN 80-86851-38-9.

[8] MĹKVA, M., KuČerovÁ, M., VeČERA, P. 2012. Application of tools and methods within "Lean manufacturing". In Carpathian Logistics Congress 2012 : November 7th - 9th 2012, Priessnitz Spa, Jeseník, Czech Republic. Ostrava : Tanger, 2012, pp.6. ISBN 978-8087294-33-8.

[9] SvozilovÁ, A. (2011). Zlepšování podnikových procesů. Praha : Grada Publishing a.s., 2011. 978-80-247-3938-0. 
[10] Miller, JoN. 101 Kaizen Templates: Spaghetti Diagram. [cit. 2018-04-28]. https://blog.gembaacademy.com/2008/02/12/101_kaizen_templates_spaghetti_diagram/.

[11]All About Spaghetti Diagrams. Online https://www.allaboutlean.com/spaghetti-diagrams/ [cit. 2018-04-28].

[12] SinAY, J., ET AL. Nástroje zlepšovania kvality. Prešov: ManaCon, 2007, 192s. ISBN 97880-89040-32-2.

[13] KIDWELL, M. 2003. Lean Manufacturing and the Environment: Ignoring the 8th Deadly Wastel leaves money on the table. Research on Advanced Manufacturing Systems and the Environment and Recommendations for Leveraging Better Environmental Performance, EPA100-R-03-005, October 2003. online at http://www.epa.gov/lean/leanreport.pdf.

[14] Sinton, JAMES R. 2010. Using Lean Thinking Approaches to Speed Sustainable Development. 2010. pp.115-132.

[15] KuBASÁKOVÁ, I. 2008. Zavádzanie logistického systému kanban do podniku pre zvýšenie kvality procesov. In: Logistický monitor. Žilinská univerzita. ISSN 1336-5851, [cit. 201804-28]. http://www.logistickymonitor.sk/en/images/prispevky/system-kanban.pdf.

[16] LIPNIČAN, M., MĹKVA, M. 2017. Uplatnenie vybraných metód štíhlosti na výrobnom úseku "assembly". Diploma thesis. MTF STU.

[17] Macharová M., MĹKVA M. 2012. Návrh aplikácie vybraných metód zlepšovania kvality na pracovisku výroby lán. Diploma thesis. MTF STU.

[18] PRACHǍ̌, J., FIDLEROVÁ, H., SAKÁL, P., ZBOJOVÁ, T., 2014 Improving the sustainability and effectiveness of the inventory management in manufacturing company. In Applied Mechanics and Materials : Novel Trends in Production Devices and Systems II. Special topic volume with invited peer reviewed papers only. Vol. 693 (2014), pp. 141146. ISSN 1660-9336.

[19] SCHACHERL, L. 2009. Řizení zásob v dodavatelsko-odběratelském řetězci. Thesis. [cit. 2018-04-28] http://dspace.upce.cz/bitstream/10195/35313/1/DDP_Schacherl_2009.pdf

[20] Co Henry C, Sharafali, Moosa, 1997. Overlapping factor in Toyota's formula for computing the number of kanbans.1997, IIE Trans 29(5):p. 409-415.

Date of sending the publication to the Editor: 21.06.2018

The date of the publication's acceptance by the Editorial Board: 29.07.2018 